\title{
Kariera jako „własność” jednostki - rozważania teoretyczne nad definicyjnym credo
}

\author{
KEY WORDS \\ job market, career, \\ career as an \\ individual's property, \\ career criteria, \\ personality
}

\begin{abstract}
Cybal-Michalska Agnieszka, Kariera jako "własność" jednostki - rozważania teoretyczne nad definicyjnym credo [Career as an Individual's, Property" - Theoretical Considerations About the Definitional Credo]. Kultura - Społeczeństwo - Edukacja nr 1, 2012, Poznań 2012, pp. 193-203, Adam Mickiewicz University Press. ISBN 978-83-232-2470-9
\end{abstract}

\begin{abstract}
The narration of this article is focused on showing various ways of capturing the phenomenon of career from a subjective perspective. The subject of an analysis will be the reconstruction of chosen theoretical perspectives, where one emphasizes changes in quality attitude to the career phenomenon and showing the "career making" meaning of people's activities. The content presented in this article is concentrated on a subjective, personal aspect of capturing a career. In this sense, career is always ascribed to a specific individual, it is their assets and this particular individual attaches importance to the career phenomenon. In this sense, career is the sequence of experiences of a particular individual, linked with the quality of a professional life; this is a unique structure, resulting from autonomous choices.
\end{abstract}

Specyfika jakościowo nowych przekształceń w relacjach pomiędzy globalnością a lokalnością, państwem a społeczeństwem, społeczeństwem a jednostką oraz powiązań między nimi nie pozostaje bez znaczenia dla organizacji życia społeczno-kulturowego, politycznego i gospodarczego. Motorem nowego (nie)porządku świata, jak konstatuje Zygmunt Bauman, są zasady wolnego rynku, które zdominowały politykę, wzniosły się w przestrzeń ponadnarodową, pozwalając na rosnące znaczenie ekonomii, i ograniczyły swobodę państw i rządów w podejmowaniu decyzji (Ziewiec, 2009). Polski myśliciel nie jest w swoich poglądach na temat ekspansji rynku i komercjalizacji osamotniony. Pokrywają się one z przemyśleniami Alvina Tofflera, Daniela Bella, R. Coopera, Johna Naisbitta, Manuela Castellsa, Anthony’ego Giddensa. Ulrich Beck już w przedmowie do swojej książki zatytułowa- 
nej Władza i przeciwwładza w epoce globalnej. Nowa ekonomia polityki światowej wyraźnie akcentuje, iż „współcześnie dokonuje się pewien twórczy, od wewnątrz powodowany rozpad "prawomocnego" ładu świata, w którym dominowały państwa narodowe" (Beck, 2005: 15). I chociaż poglądu tego nie można przyjmować bezkrytycznie, bowiem „w pełni wolny rynek funkcjonuje jako ideologia, mit lub wzorzec, ale nigdy jako codzienna rzeczywistość" (Wallerstein, 2007: 43; za: Ziewiec, 2009: 87), jak podkreśla Immanuel Wallerstein, to nie ulega wątpliwości, że codzienność uczy, aby nie wiązać nadziei na poprawę jednostkowego losu z państwem, jego polityką czy społeczeństwem. Świat wielości i różnorodności, będący in statu nascendi (którego doświadczamy i który domaga się permanentnego rozpoznawania), nie ma tego rodzaju ambicji. To świat indywidualnie wypracowanych i urzeczywistnianych strategii, które muszą być adekwatne do tempa zmian, jakim podlega otoczenie (Ziewiec, 2009: 83-92). Zwrócenie uwagi na jakość globalnej „ekumeny kulturowej” (U. Hannerz) skłania do refleksji nad globalnymi zmianami w stylach życia, co nie pozostaje bez znaczenia dla jakości zmian w świecie pracy i praktyki planowania kariery i zarządzania nią.

Efektem tych przemian jest zwrócenie uwagi na jakość systemu organizacji pracy (elastyczność pracy pozwala na adekwatne reagowanie na zapotrzebowanie rynku pracy) oraz wzrost znaczenia jakości satysfakcji z wykonywanej pracy (nierzadko poprzez zmianę jej funkcji czy treści) i stopniowy zanik tradycyjnego modelu rozwoju kariery (Strykowska, 2001: 120). Dynamika przemian współczesnego świata pracy, a nawet „końca pracy” (J. Rifkin) aktualizuje rolę jakości wykształcenia i wymaganych kwalifikacji. Ilustracją zarysowanych przemian na wysoce konkurencyjnym i wymagającym rynku pracy jest stwierdzenie: „krótkoterminowe projekty stają się bardziej powszechne niż stanowisko pracy w jednej firmie na okres stały [...], a przełomowym oraz decydującym zjawiskiem staje się wszechstronność kwalifikacji (multi-skilling)" (Maree, 2010: 362). Globalne tendencje i procesy różnicowania, wielokontekstowości, wielowymiarowości i współzależności różnych dziedzin życia społecznego niewątpliwie aktualizują problem implementacji idei life long learning, planowania, zarządzania, rozwoju i kształtowania kariery oraz skłaniającą do namysłu nad problemem kariery jako „własności” jednostki.

We współczesnym, zindywidualizowanym społeczeństwie, kreującym nowe style życia, kwestią fundamentalną staje się "nowy sposób myślenia o karierze” (W. Lanthaler). Konceptualizacja jakościowo nowego ujęcia problematyki kariery jako „własności” jednostki (współwystępującego w sąsiedztwie tradycyjnego rozumienia kariery jako strukturalnej własności organizacji czy zawodu) wskazuje na wielowymiarowy charakter współczesnego dyskursu, który łączy w sobie implikacje interdyscyplinarnego dialogu i stwarza potrzebę przeglądu teoretycznych refleksji nad sposobami rozumienia kariery oraz uwarunkowań i wyznaczników jej kształtowania. 
Próbując dookreślić kategorię pojęciową „kariera”, trudno nie zauważyć braku ostrości i niejednoznaczności w semantycznych sensach przypisywanych temu pojęciu. Ponadto wyróżnikiem myślenia o karierze jest różnorodność znaczeń, w których to pojęcie bywa używane. Zakresem pojęcia „kariera” może być jego subiektywna i obiektywna struktura znaczeniowa, wartościujące (również o negatywnym wycieniowaniu, jak kategorie: „karierowicz”, „karierowiczostwo”l) i nie wartościujące (będące wyznacznikiem myślenia o karierze jako „własności” jednostki) rozumienie, czy też ujmowanie zagadnienia, z perspektywy organizacji albo podmiotu.

O karierze można mówić jako o zjawisku społecznym. Ujmując temat z perspektywy socjologicznej, należy stwierdzić, że etos kariery pozostaje $\mathrm{w}$ ścisłym związku z wartościami uznawanymi w społeczeństwie, jest wszechobecny w jego kulturze i drogą transmisji zostaje zlokalizowany i silnie zakorzeniony w świadomości społecznej. Niewątpliwie jest on społecznie propagowany, co nie pozostaje bez znaczenia dla ukierunkowania aktywności ludzkiej. W efekcie dążenia do jego osiągnięcia spotykają się z aprobatą społeczną (Rokicka, 1992: 116). Na marginesie podjętych dociekań znajduje się odwołanie do historycznego kontekstu omawianego zagadnienia. Znaczące źródło „karierotwórczej” siły jednostek stanowił triumf stosunków kapitalistycznych. Postawiona teza jest najzupełniej usprawiedliwiona, bowiem, jak ujmuje Z. Bauman, człowiek po upadku struktury feudalnego społeczeństwa po raz pierwszy: ,stanął na własnych nogach [...], zdany był całkowicie na własną inicjatywę i spryt. Po raz pierwszy nic w jego pozycji nie było oczywiste i raz na zawsze dane" (Bauman, 1960: 14). Odtąd społeczeństwo stało się terenem dla przejawiania inicjatywy jednostek, przestrzenią bez limitu tworzenia, bankiem wielu możliwości, szans i perspektyw dostępnych każdemu, kto ukierunkuje się na ich dostępność. Kolejną osobliwością zarysowanych warunków społecznych jest fakt, iż dopiero w nich można orzekać o „karierze”, a nie o „ruchliwości pionowej”, która ma swoją tradycję, znacznie bardziej utrwaloną od kapitalizmu. Dopiero w etosie kapitalizmu zauważamy - jak ujmuje to Z. Bauman - że „kariera robi karierę” (Bauman, 1960: 14-15, 28-29). Baumanowska teza, że „«ruchliwość pionowa jednostek» przekształca się w społeczny problem kariery [...] wtedy, gdy pozycje społeczne jednostek nie są raz na zawsze prawnie uregulowane, gdy jednostka w swym dążeniu do zdobycia określonego miejsca w społe-

1 Termin „kariera” jest, jak usystematyzował to Z. Bauman, również terminem moralnym związanym z określonym systemem wartościowania życiowych postaw, relacji z otoczeniem, jak również obowiązków wynikających z tych stosunków. Biorąc pod uwagę etos kapitalizmu, autor wskazuje na pewien paradoks, a mianowicie: „głosząc chwałę sukcesu i tych, co sukces odnieśli, potępia jednak świadome dążenie do osobistego sukcesu «za wszelką cenę», a z karierą jako motywem postępowania wiąże nikłe raczej walory moralne. Dążenie do kariery zostało zepchnięte do rzędu chorób wstydliwych, a dla dotkniętych tą chorobą ukuto termin «karierowicz», wyposażając go w spory ładunek moralnego potępienia”. Bauman, 1960: 25. 
czeństwie skazana jest na własne siły, i gdy w rezultacie wspinaczka społeczna staje się ideologią, pobudzającą do czynu tysiące i miliony ludzi” (Bauman, 1960: 15), współbrzmiewa z przyjętą współcześnie przez psychologów perspektywą ujmowania kariery jako „własności” jednostki. Jednostki, jak podkreślają B.G. Glaser i A.L. Strauss, „«wędrują» między statusami, które współtworzą we współdziałaniu i interakcjach z innymi, zwrotnie zyskując potwierdzenie własnych wyobrażeń o sobie i własnej tożsamości” (Rokicka, 1992: 116). To ważkie dostrzeżenie subiektywnych aspektów kariery, takich jak: status jednostki, koncepcja siebie jako podmiotu, reakcje społeczne na odgrywanie ról, sprawia, że jednostki nie są ujmowane jako „byt stabilny”. Jaźń, która jest relacyjna i powstaje w procesach uspołecznienia, jest raczej „wielością rzeczywistości niż jedną rzeczywistością” (Hałas, 2007: 115). O koncepcji kariery E. Goffman powie, że „umożliwia poruszanie się w przód lub wstecz pomiędzy [...] własnym Ja a społeczeństwem, które jest dla tego Ja ważne” (Blankenship, 1973: 92).

Ujmowanie kariery jako „własności jednostki” (Baruch, 2004, Bańka, 2005a) przyjmuje indywidualistyczne założenie o niepowtarzalnej jakości kariery każdego człowieka, bowiem jest ona „zgromadzeniem przez jednostkę serii unikalnych stanowisk, prac, pozycji i doświadczeń zawodowych" (Bańka, 2005b: 23) i odpowiedzialności podmiotu za konstruowanie swoich karier. Właściwością kariery jest niewątpliwie jej procesualny charakter. W kontekście kariery dookreślonej przez przymiotnikowy kawalifikator „zawodowej” wskazuje się na proces, któremu podlega jednostka w miarę doświadczania i praktykowania pracy zawodowej. $\mathrm{Na}$ gruncie znanych teorii rozwoju kariery, że warto przywołać chociażby perspektywę teoretyczną D.C. Millera i W.H. Forma (1951), D.T. Halla i Nougoima (1968), D. Supera (1980), J.G. Greenhausa i G.A. Callalana (1994), A. Paczkowskiego (1998), A. Kargulowej (2005), J. Szczupaczyńskiego „rozwój kariery rozpoczyna się wraz z początkiem życia i trwa nieprzerwanie do jego końca” (Wołk, 2009: 20-21).

Kategoria „kariery” może być definiowana jako konstelacja wielu funkcji pełnionych przez jednostkę jednocześnie bądź sekwencyjnie w ciągu całego życia. Mogą się one wzajemnie uzupełniać albo zastępować, ale mogą także pozostawać w konflikcie. Za punkt odniesienia w omawianym podejściu do zagadnienia „kariery” D. Super oraz M. Bohn przyjmują definicję funkcji rozumianej jako „zbiór społecznych oczekiwań, jakie ma społeczeństwo lub grupa społeczna wobec jednostki zajmującej w tej społeczności określoną pozycję" (Paszkowska-Rogacz, 2004: 112). Strategie rozwoju kariery aktualizowane są droga pełnionych funkcji społecznych (Paszkowska-Rogacz, 2004: 107-110). Jednocześnie, na co zwraca uwagę D. Super, kariera jako pasmo wydarzeń składających się na sekwencję zawodów i funkcji pełnionych przez jednostkę w biegu jej życia zgodnie z jej zindywidualizowanym wzorem samoregulacji (Szymański, 2010: 77) jest „szansą jednostki na urzeczywistnienie koncepcji siebie" (Miś, 2006: 483), co w sposób bezpośredni akcentuje wymiar 
subiektywny w nurcie rozważań nad możliwym przebiegiem kariery. W podobnym kierunku zwróciły się dociekania D.T. Halla. Zdefiniował on „karierę” jako „proces trwający przez całe życie i składający się z sekwencji aktywności, postaw, powiązanych stanowisk i zachowań, które mają miejsce w życiu zawodowym jednostki” (Adekola, 2011: 100). W omawianym przez autora ujęciu „kariery” jako sekwencji doświadczeń związanych z pełnioną funkcją istotę stanowi rzeczone doświadczenie i jego udział w kształtowaniu i ugruntowywaniu się procesów psychicznych, do których badacz zalicza: samoocenę, postawy, system wartości, aspiracje, stopień satysfakcji (Szymański, 2010: 79). Ten nurt dociekań znajduje również swoje odzwierciedlenie w ustaleniach definicyjnych A. Kargulowej. Ich podmiotowe wycieniowanie pozwala autorce na uznanie, iż kariera jest „listą wydarzeń składających się na życie, sekwencje zawodów i innych ról życiowych, które razem wyrażają stosunek do danej osoby, do pracy w aspekcie jej całkowitego procesu rozwojowego" (Kargulowa, 2005: 21).

Omawiany pogląd na karierę znajduje odzwierciedlenie w rozważaniach J.G. Greenhausa (2000). Jego poglądy na karierę zostały zdefiniowane przez ukazanie z jednej strony doświadczeń związanych z pracą (decyzje związane z pracą, zajmowana pozycja, obowiązki, funkcje i role zawodowe), a z drugiej - subiektywnych interpretacji wydarzeń zawodowych (wskazując na aspiracje, wartości, potrzeby, nastawienia odczucia i oczekiwania związane z konkretnymi doświadczeniami zawodowymi) w toku całego życia jednostki (Adekola, 2011: 100). Kariera w rozumieniu J.H. Greenhausa i G.A. Callanana (1994) to jakość doświadczeń skoncentrowanych na pracy, wyznaczających kierunek jakości życia podmiotu (Greenhaus, 1994: 5). W miarę nabywania przez jednostkę doświadczeń możliwości projektowania ścieżki kariery poszerzają się i nabierają cech holistycznego jej ujmowania. Zaproponowane przez E.L. Herr i S.H. Cramera rozważania teoretyczne na temat „kariery” stanowią próbę przybliżenia tego ujęcia. Kariera, która jest unikalna dla każdego podmiotu (strukturalnie wypełniona tym, co jednostka wybrała, ale i nie wybrała), dynamiczna i zmienna, „zawiera w sobie nie tylko wykonywany zawód, ale też decyzje sprzed okresu podjęcia pracy oraz wszystkie te, które jednostka podejmuje po okresie aktywności zawodowej, a także związki pracy z innymi rolami odgrywanymi przez jednostkę w rodzinie, w społeczności, w czasie wolnym od pracy" (Szymański, 2010: 81). A. Miś, starając się dokonać syntezy wiedzy na temat współczesnego ujmowania natury kariery jednostki, akcentuje, iż jest to „unikatowa sekwencja zawodów i stanowisk, wartości oraz ról odgrywanych przez jednostkę w ciągu jej życia, kształtowana przez okres poprzedzający pracę zawodową i wpływająca na okres późniejszy" (Miś, 2006: 478).

W przywołanym stanowisku ujmowania kariery jako „własności” jednostki można wyróżnić, co porządkuje A. Bańka, kilka odmian jej ujmowania, wskazując na wybrane dystynktywne kryterium kariery: 
Kryterium awansowe, które implikuje łączenie rozwoju i realizacji osobistej kariery ze stałymi i szybkimi awansami (najczęściej w statusie, zarobkach, prestiżu, władzy), należy do często spotykanych (Bańka, 2005b: 24). Akcentując długość drabiny awansu, za istotę kariery przyjmuje się wielkość dystansu pomiędzy „punktem wyjścia jednostki a dojścia” (Worach-Kardas, za: Szymański, 2010: 80). Pragnienie kariery, utożsamiane z praktyką awansów, jest motorem i drogowskazem (dostarczonych i wyprowadzonych z hierarchii społecznych wartości) działania podmiotu. Jest to kwestia, jak ujmuje to Z. Bauman, faktu, iż jednostka upatruje sobie „miejsce o większym splendorze, bogactwie czy władzy niż to, jakie aktualnie zajmuje. Widzi wyraźnie drogę, która ma go do tego miejsca doprowadzić, i żywi nadzieję, że starczy [...] sił na jej przebycie - jest więc gorliwym obrońcą i zwolennikiem społeczeństwa, w którym znajdują się te ponętne miejsca i drogi, które do nich prowadzą" (Bauman, 1960: 16-17). Dobrym przykładem jest przywołana przez D.T. Halla kategoria „kariery” utożsamianej ze ścieżką rozwoju zawodowego, wiążącego się z koniecznością zajmowania pozycji, dla których przewidziana jest droga awansu oraz adresowana jest do zawodów o dużym prestiżu . Typologia ujęć rozumienia kariery D.T. Halla obejmuje również jej identyfikowanie z „zaawansowaniem”, co sprowadza się do stwierdzenia, iż „dokonuje się ona przez uzyskiwanie «czegoś więcej» - mogą to być coraz wyższe stanowiska w strukturze organizacyjnej, praca w organizacji postrzeganej jako «lepsza», szersze możliwości decyzyjne lub większa rozpiętość władzy" (Miś, 2006: 477). Egzemplifikacją kariery w omawianym sensie jest realnie zwiększony zakres przywilejów. Posiada ono jednak swoje ograniczenia co do ram znaczeniowych pojęcia „kariera”. Omawiane stanowisko, będące $\mathrm{w}$ dużym stopniu wyznacznikiem socjologicznego wymiaru ujmowania kariery (utożsamiającego awans zawodowy z awansem społecznym), chociaż pozbawia jednostkę miana posiadania czy rozwoju kariery w przypadku, kiedy nie doświadcza ona awansów zawodowych (Bańka, 2005b: 24), to jednak odwołuje się do sekwencji doświadczeń jednostki.

Kryterium zawodu jest równie często jak dystynktywne kryterium awansu kojarzone z „robieniem” kariery. Zawody konstytuujące karierę (a do takich zalicza się między innymi zawód lekarza i prawnika), charakteryzują się wysokim statusem, prestiżem, władzą i możliwościami awansu (Bańka, 2005b: 24). W wyróżnionym sensie, jak ujmuje to w opracowanej przez siebie typologii D.T. Hall, kariera odnosi się tylko do „zawodów, w których jasno określona jest ścieżka rozwoju zawodowego, wytyczona następstwem stanowisk [...] i dokonuje się przez kumulację wiedzy i umiejętności z góry określoną wymogami kolejnego stanowiska" (Miś, 2006: 477). Wyróżniona perspektywa ujmowania kariery nie jest wolna od nasuwającej się, podobnie jak w przypadku wcześniej omawianego kryterium, sugestii, że osób bez określonego statusu społecznego czy zawodowego kategoria kariery nie obejmuje (Bańka, 2005b: 24). A przecież z perspektywy podmiotowej kariera 
jest często "tylko historią pełnionych funkcji oraz pozycji, jakie udało się osiągnąć jednostce" (Duda, Kukla, 2010: 40).

Kryterium stabilności w obszarze pojedynczego pola zawodowego czy też w ramach pól ściśle ze sobą powiązanych to trzecie dystynktywne kryterium pojmowania kariery. Stabilność, ciągłość i systematyczność powiązań w treści prac lub aktywności równa się realizacji kariery (np. „kariery nauczycielskiej”, „kariery naukowej”, „kariery żołnierskiej”), a brak tych atrybutów dowodzi braku konstytuowania kariery przez jednostkę (Bańka, 2005b: 24). Egzemplifikację utożsamiania kariery $\mathrm{z}$ atrybutem stabilności stanowi definicja autorstwa A. Pocztowskiego, w której akcentuje się, że kariera to „kolejne stanowiska pracy, związane z określoną pozycją w hierarchii organizacyjnej, które pracownik zajmuje w okresie zatrudnienia w danym przedsiębiorstwie" (za: Szymański, 2010: 80).

Kryterium praktykowania pracy zostało również dostrzeżone i wyróżnione przez D.T. Halla. Kariera jako atrybut przypisany wyłącznie jednostkom pracującym oznacza „indywidualny wzorzec kolejno wykonywanych prac" przez jednostkę w toku jej życia zawodowego (Miś, 2006: 477). Nie wartościując jakości wykonywanej przez jednostkę pracy czy praktykowanego zawodu, J. Szczupaczyński definiuje karierę jako „sekwencję stanowisk pracy i zawodów, jakie pracownik zajmuje i wykonuje w czasie zatrudnienia lub w całym okresie aktywności zawodowej” (Szymański, 2010: 79). W wyróżnionym nurcie definiowania kariery kluczową rolę odgrywa określona w „czasie sekwencja kolejno obejmowanych ról zawodowych, począwszy od wejścia na rynek pracy, a skończywszy w danym punkcie czasowym lub wraz z wyjściem z rynku pracy" (Słomczyński, 2007: 21). Podobnie, jako własność jednostki pracującej, lokuje rozumienie kariery B. Jamka, uznając, iż jest to „ciąg, następstwo obejmowanych przez pracownika stanowisk, wykonywanych prac i (lub) pełnionych funkcji” (Jamka, 1998: 142). Kariera jest atrybutem każdej jednostki pracującej i stanowi zapis jej pracy zawodowej (Szymański, 2010: 78).

Współczesne ujęcie definicji kariery nie ogranicza się jedynie do aspektów związanych z praktyką awansów, posiadaniem określonego zawodu, satysfakcjonującą sytuacją zawodową jednostki czy też stabilnością wewnętrznych powiązań treści praktykowanego zawodu. Znacznie szerszy zakres tego, co denotuje i konotuje pojęcie „kariera”, zawiera w sobie „oprócz sytuacji czysto zawodowej [...] również poziom dobrostanu psychicznego, rozumianego jako brak napięć dezorganizujących aktywność jednostki, dostatek ekonomiczny i społeczny, oraz pomyślną sytuację rodzinną" (Bańka, 2005a: 8).

We współczesnych ujęciach kariery podkreśla się wagę aktywności niezwiązanych bezpośrednio $\mathrm{z}$ pracą, takich jak: sposoby spędzania czasu wolnego, formy rekreacji, edukacja, pełnienie funkcji rodzinnych, które wiążą się zatrudnieniem (Bańka, 2005b: 26). W tym mniej restrykcyjnym podejściu do definiowania „kariery” podkreśla się wagę konstruowania (a nie wybierania) kariery dla projekto- 
wania jakości życia (Maree, 2010: 362). Tak rozumiana kariera, jak ujmuje to D.T. Hall, oznacza sekwencję doświadczeń jednostki, rozumianych jako „kształtowanie się wewnętrznych procesów jednostki, takich jak: dążenia i aspiracje, satysfakcja, wyobrażenia o sobie, postawy wobec pracy pod wpływem zmieniających się ról" (Miś, 2006: 477), związanych z pełnioną przez nią funkcją zawodową, składającą się na jej historię życia zawodowego. Jak ujmuje to A.S. King, „psychologiczna siła własnej tożsamości, wgląd w siebie i wytrzymałość w dążeniu do realizacji celów kariery reprezentują główne komponenty motywacji i „poświęcenia” (rozumianego jako zaangażowanie - dop. A. C-M) się karierze, a także współpracy, spoistości [...] w organizacji” (Adekola, 2011: 104). Jednostka jako indywiduum nadaje swoiste indywidualne znaczenia wybranym elementom rzeczywistości dzięki umiejętności odczytywania kodów kulturowych, stwarza własną indywidualną historię i ma przed sobą historię. Konstruuje własne życie, a tym samym, osobistą karierę, „poprzez identyfikację (nadawanie znaczeń) z własnymi zawodowymi zachowaniami i licznymi doświadczeniami w miejscach pracy" (Maree, 2010: 363), nadając także znaczenie kontekstowi, w którym owe doświadczenia zachodzą. Najbardziej bodaj charakterystycznym nurtem rozważań skoncentrowanych na subiektywnym aspekcie kariery (obok zaakcentowania charakterystycznego dla interakcjonizmu, obiektywnego aspektu jej ujmowania) jest Goffmanowska kategoria „kariery duchowej” (moral career) rozumianej jako reakcje jednostki na siebie samą w określonych sytuacjach, powodujące permanentne zmiany w koncepcji własnego Ja. W prezentowanej orientacji teoretycznej akcentuje się badanie kariery w wewnętrznym wymiarze, co oznacza studia nad zmianami, jakie zachodzą w tożsamości podmiotu oraz jego wyobrażeniach na temat siebie i innych podmiotów życia społecznego (Rokicka, 1992: 125). Wzięcie przez jednostkę odpowiedzialności za poszukiwanie znaczenia swojej roli w praktykowanym zawodzie, którego źródłowość Ch. Handy, autor pracy zatytułowanej The Age of Paradox, upatruje w kierunku (jednostkowe poczucie działania w słusznej sprawie), ciągłości (wiara podmiotu w przetrwanie i kontynuowanie wytworów jego pracy) oraz łączności (udział we wspólnocie z którą się identyfikujemy i współtworzymy), jest procesem całożyciowym i zadaniem całożyciowego uczenia się (Piotrowska, 2006: 11). Brytyjski uczony dodaje, że „znaczenie przyjdzie do tych, którzy rozwijają własne poczucie kierunku, ciągłości i łączności” (Biolos, 2006: 30) w tym, co zawodowo praktykują.

Istotę stanowi sekwencyjny rozwój jednostki (integralnie związany z rozwojem jej kariery) w trakcie całego życia jednostkowego. Nieprzypadkowo, bacząc $\mathrm{w}$ istocie na praktykę poznawczą $\mathrm{w}$ konstruowaniu modelu doradztwa zawodowego, V.G. Zunker kluczową rolę w projektowaniu życia zintegrowanego z konstruowaniem kariery przypisuje percepcji sukcesu przez podmiot, jego motywacji do pracy, jednostkowej potrzebie wewnętrznej satysfakcji, podejmowanym rolom, jakości relacji z innymi partnerami życia, zmianom rozwojowym oraz kontekstu- 
alnym (Maree, 2010: 364). W tym ujęciu, jak podkreśla między innymi J.H. Greenhaus, „karierę” ujmuje się jako „wzór doświadczeń związanych z pracą, który spina i wytycza podstawowy kierunek życia jednostki" (Bańka, 2005b: 24). W tym sensie za J. Arnoldem można powiedzieć iż „szerokie ujęcie kariery zakłada, że jest to sekwencja pozycji związanych z zatrudnieniem, ról, aktywności i doświadczeń" (Bańka, 2005b: 24) zdobytych przez podmiot w czasie całożyciowego rozwoju.

Reasumując, należy podkreślić, iż ważkim elementem wyróżnionych definicji ujmowania „kariery” jest ich wyraźne podmiotowe, personalne wycieniowanie. "Skoro już człowiekowi w określonym społeczeństwie żyć wypadło, chce on zająć w nim upatrzone, szczególnie mu odpowiadające miejsce" (Bauman, 1960: 16), jak konstatuje Z. Bauman. Kariera zawsze jest przypisana do konkretnej jednostki, jest stanem jej posiadania i to ona nadaje jej swoiste indywidualne znaczenie. Nie zwracamy się w stronę akcentowania praktykowanego zawodu (np. wykonuję zawód...), lecz „bycia” reprezentantem wykonywanego zawodu (np. jestem...). Zawód jest jedynie kontekstem, w ramach którego rozwija się kariera własna, która jest udziałem każdego, kto pracę wykonuje, bądź nawet (jak w przypadku bezrobotnych) jej poszukuje (Bańka, 2005b: 25). W tym sensie każda podmiotowa kariera posiada unikatowy charakter. Nic w tym dziwnego, bowiem jednostkowe marzenia, pragnienia, tęsknoty i wyobrażenia składają się na własny, najbardziej osobisty model ideału życiowego (Bauman, 1960: 18). Analizując karierę z perspektywy jednostkowej, jako „własność” jednostki aktualizowanie cech tkwiących w pomiocie powinno być zintegrowane z jego cechami osobowości i typem przejawianej orientacji na karierę. Uniwersalne przesłanie o potrzebie aktualizowania potencjału tkwiącego w podmiocie, o potrzebie aktualizowania zachowań proaktywnych i kształtowania orientacji prorozwojowej jest odzwierciedleniem marzeń o nowym sposobie bycia w świecie.

\section{Literatura}

Adekola B. (2011). Career Planning and Career Management as Correlates for Career Development and Job Satisfaction. A case Study of nigerian bank Employees. [In:] „Australian Jurnal of Business and Management Research" no 2

Bańka A. (2005a). Motywacja osiągnięć. Poznań-Warszawa

Bańka A. (2005b). Proaktywność a tryby samoregulacji. Poznań-Warszawa

Baruch Y. (2004). Managing Careers: Theory and Practices. Harlow

Bauman Z. (1960). Kariera. Warszawa

Beck U. (2005). Władza i przeciwwładza w epoce globalnej. Nowa ekonomia polityki światowej. Warszawa

Biolos J. (2006). Modele kariery XXI-go wieku. [W:] Zarządzanie kariera. Warszawa

Blankenship R.L. (1973). Organizational Careers: In Interactionist Perspektive. „The Sociological Quarterly" 14 
Duda W., Kukla D. (2010). Kariera zawodowa wobec postępujących przemian pracy. Częstochowa Greenhaus J.H., Callanan G.A. (1994). Career Manageent. Fort Worth, TX

Hałas E. (2007). Symbole i społeczeństwo. Szkice z socjologii interpretacyjnej. Warszawa

Jamka B. (1998). Planowanie kariery pracowników. [W:] M. Rybak. Zarządzanie zasobami ludzkimi w firmie. Warszawa

Kargulowa A. (2005). O teorii i praktyce poradnictwa. Warszawa

Maree J.G. (2010). Brief Overview of the Advancement of Postmodern Approaches to Career Counseling. „Journal for Psychology in Africa” 20(3)

Miś A. (2006). Kształtowanie karier w organizacji. [W:] H. Król, A. Ludwiczyński. Zarzadzanie zasobami ludzkimi. Warszawa

Paszkowska-Rogacz A. (2004). Koncepcje wartości oraz modele życia związane z planowaniem kariery zawodowej. [W:] Pedagogika pracy. Doradztwo zawodowe. Red. H. Bednarczyk, J. Figurski, M. Żurek. Radom

Piotrowska D. (2006). Wstęp. [W:] Zarzadzanie karierą. Warszawa

Rokicka E. (1992). Pojęcie „kariery”. Perspektywa strukturalno-funkcjonalna i interakcjonistyczna. „Przegląd Socjologiczny” XLI

Słomczyński K. (2007). Kariera i sukces. Analizy socjologiczne. Zielona Góra

Strykowska M. (2001). Globalizacja a kariery zawodowe. [W:] Społeczne problemy globalizacji. Red. Z. Blok. Poznań

Super D. (1942). The Dynamics of Vocational Adjustment. New York

Super D. (1990). A Life-Span, Life-Space, Approach to Career Development. [In:] Career Choice and Development. Eds. D. Brown, L. Brookes. San Francisco

Szymański M. (2010). Ścieżki kariery studentów socjologii. Warszawa

Wallerstein I. (2007). Analiza systemów-światów. Wprowadzenie. Warszawa

Wołk Z. (2009). Kultura pracy, etyka i kariera zawodowa. Radom

Ziewiec G. (2009). Nowy niewspaniały świat. Globalizacja i demokracja liberalna z perspektywy Zygmunta Baumana. „Studia Socjologiczne” nr 3

\section{Career as an Individual's „Property" - Theoretical Considerations about the Definitional Credo}

\section{Summary}

The peculiarity of quality new transformations in the relations between globality and locality, nation and a society, a society and an individual and connections between them, is not without meaning for the organization of socio-cultural, political and economic life. The driving force of new (dis)order of the world, as Z. Bauman states, are rules of the free market, which dominated the politics, rose into the transnational space and allowed economy to gain more importance and restricted countries and governments in their decision making freedom, which is not without meaning for new judgments about the condition of a contemporary man. Paying attention to the quality of changes of the contemporary world inclines reflections about global changes in lifestyles, which is significant for the quality of changes in the job world and the practice of career planning and management. Global tendencies and processes of differentiation, multi-contextuality, many-sidedness and interdependence of various spheres of social life, 
undoubtedly update the problem of planning, management, development and shaping of career and they induce reflections about the problem of career as an individual's "property".

In the contemporary, individualised society, which creates new lifestyles, "a new way of thinking about career" (W. Lanthaler) becomes a fundamental matter. Conceptualization of quality new apprehension of career issues as an individual's "possession", (which co-occurs with traditional understanding of career, as a structural property of an organization or of a profession) indicates a many-sided character of a contemporary discourse, which combines implications of an interdisciplinary dialogue and creates the need to review theoretical reflections about the ways of understanding career and conditions, as well as indicators of its formation.

Career can be discussed in terms of a social phenomenon. Looking at the subject from a social perspective, the ethos of career remains in a close relationship with the values of a given society, it is omnipresent in its culture and, through transmission, it is localised and strongly rooted in the social consciousness. Undoubtedly, the ethos of career is socially propagated, which is not without meaning for giving direction to people's activities. As a result, attempts to achieve a career are socially approved.

The processual character is, unquestionably, a feature of career. In the context of the career, which is also defined as "professional", one points to the process, which individuals undergo, as they experience and practice professional work. The "career" category can be defined as a constellation of many roles, which individuals play simultaneously or sequentially during their whole life. The roles individuals play may complete or substitute each other but they also may remain in conflict.

In this attitude towards career, as an individual's "property", one can distinguish, what A. Bańka arranges, a few ways of its apprehension, which point to a chosen, distinctive career criterion. One can often encounter a promotion criterion, which implicates combining the development and realization of a personal career with permanent quick promotions (most often in status, earnings, prestige and power). The profession criterion is, as often as the promotion criterion, associated with "making" a career. Professions that constitute a career (a doctor or a lawyer, among others) are characterised by high status, prestige, power and promotion possibilities. The third distinctive career criterion is the criterion of stability in a single professional sphere or in spheres, which are closely related. Stability, continuity and regularity of relations, in the content of jobs or activities, equal career realization and the lack of these attributes prove that an individual does not constitute a career.

The contemporary apprehension of the definition of a career does not limit itself only to the aspects linked with the practice of promotions, having a specific profession, a satisfactory professional situation or the stability of inner relations of the content of a given job. A far wider scope of what denotes and connotes the term "career" includes, apart from a purely professional situation, also the level of mental well-being, understood as the lack of tensions disrupting an individual's activity, economic and social welfare and a happy family situation. Individuals give specific peculiar meanings to chosen elements of the reality, thanks to the ability to read cultural codes and they create their own individual history and they have a history ahead of them.

Individuals construct their own lives and, thereby, their personal careers through identification (giving meanings) with their own professional behaviours and numerous experiences in job places, giving also meaning to the context of these experiences.

To sum up, it is important to emphasize that clear subjective and personal nuance in the subject of career is a significant element of distinguished definitions of "career". Career is always ascribed to specific individuals, it is their assets and it is these individuals who give it a peculiar, distinctive meaning. 
